\title{
SYNGENETIC INCLUSIONS OF YIMENGITE IN DIAMOND FROM SESE KIMBERLITE (ZIMBABWE) - EVIDENCE FOR METASOMATIC CONDITIONS OF GROWTH
}

\author{
G.P. Bulanova ${ }^{1}$, E. Muchemwa ${ }^{2}$, G. Pearson ${ }^{3}$, B.J Griffin ${ }^{4}$, S. Kelly ${ }^{5}$, S. Klemme ${ }^{6}$ and C.B. Smith ${ }^{7}$ \\ ${ }^{1}$ University of Bristol, United Kingdom; ${ }^{2}$ Rio Tinto Zimbabwe Ltd, Zimbabwe; ${ }^{3}$ University of Durham, United Kingdom; ${ }^{4}$ \\ University of Western Australia, Australia, ${ }^{5}$ Open University, United Kingdom; ${ }^{6}$ Institute of Mineralogy, Heidelberg \\ University, Germany; ${ }^{7}$ Consultant to Rio Tinto Mining and Exploration, United Kingdom
}

\begin{abstract}
Syngenetic inclusions of the alkali-titanate yimengite have been recorded in an octahedral diamond from the Cambrian-aged Sese kimberlite. Cathodoluminescence (CL) imaging has shown simple octahedral zonation of the diamond, lack of cracks and the location of five yimengites in different diamond growth zones.

$\mathrm{N}$ content (at. ppm) in the diamond decreases from the $576(40 \% 1 \mathrm{aB})$ in the core to the $146(30 \% 1 \mathrm{aB})$ in the rim. At an assumed 2.0 Ga mantle residence time FTIR data indicate practically constant temperature $1130^{\circ} \mathrm{C}$ of diamond formation.
\end{abstract}

Whilst ages from $530 \mathrm{Ma}$ (kimberlite eruption age) to $891 \mathrm{Ma}$ were determined from ${ }^{40} \mathrm{Ar} /{ }^{39} \mathrm{Ar}$ dating of yimengites, time- $\mathrm{T}^{\circ} \mathrm{C}$ constraints from $\mathrm{N}$ aggregation systematics combined with $\mathrm{T}(\mathrm{Zn})$ and ol-sp thermometry gave a range of possible ages from 530 Ma to Archean.

The intergrowth of yimengite with spinel designates a peridotitic paragenesis for the diamond. Compared with the published chemistry of yimengite from kimberlites, inclusions from the Sese diamond contain higher $\mathrm{Al}$, $\mathrm{Mg}$, and $\mathrm{Sr}$ and have lower concentration of $\mathrm{Fe}^{3+}$.

The chondrite-normalised REE pattern of the yimengite shows enrichment in LREE and depletion in HREE, but LREE/HREE fractionations are lower than for LIMA mantle titanates and rather similar to the REE concentrations in kimberlite and lamproite rocks.

The general trend of chemistry found for chromite inclusions in Sese diamonds is $\mathrm{Fe}, \mathrm{Cr} \rightarrow \mathrm{Mg}, \mathrm{Al}, \mathrm{Ti}$ providing evidence about metasomatic events during diamond formation. Zn-thermometry of chromite indicates that this metasomatism could have been accompanied by an increase in temperature from $1050^{\circ}$ to $1225^{\circ} \mathrm{C}$. Further progressive metasomatic alteration of Cr-Ti-spinel by a fluid rich in Ti, K, Ba and LREE may eventually result in formation of yimengite.

\section{INTRODUCTION}

Yimengite, a member of the magnetoplumbite mineral group, has been found as a diamond inclusion during study of diamonds from Sese kimberlites, $60 \mathrm{~km}$ ESE of Zvishavane, Zimbabwe. This mineral was previously reported from heavy mineral concentrates from kimberlites (Dong et al., 1983; Nixon and Condliffe, 1989; Kiviets et al., 1998). Related titanates include Srmagnetoplumbite from a Sputnik diamond (Sobolev et al., 1988) and hawthorneite found in a metasomatised harzburgite xenolith from kimberlite (Peng and Lu, 1985).

The origin of yimengite in upper mantle rocks has been interpreted as metasomatic alteration of high $\mathrm{Cr}$ spinel by $\mathrm{K}$ and Ba-rich fluids (Haggerty, 1987; Nixon and Condliffe, 1989). This paper discusses the yimengite geochemistry, its age of formation and its link with diamond origin and general metasomatic processes in the continental lithospheric mantle.

\section{DESCRIPTION OF THE DIAMOND AND METHODS OF STUDY}

A pale-brown slightly resorbed step-layered octahedral diamond contained five black yimengite inclusions (40$100 \mu \mathrm{m})$ that have "negative diamond" shapes typical of syngenetic diamond inclusions. A plate was prepared by polishing the diamond parallel to the dodecahedron, exposing yimengite inclusions on the surface.

Anomalous birefringence (ABR) (Fig. 1) and cathodoluminescence demonstrated the diamond has simple octahedral zonation and blue CL colour. The core diamond growth zone contained three yimengite inclusions, one of which was exposed by the polishing. Another yimengite from the rim zone was exposed on the other surface of diamond plate (Fig. 2). ABR and CL images displayed a lack of cracks within the 


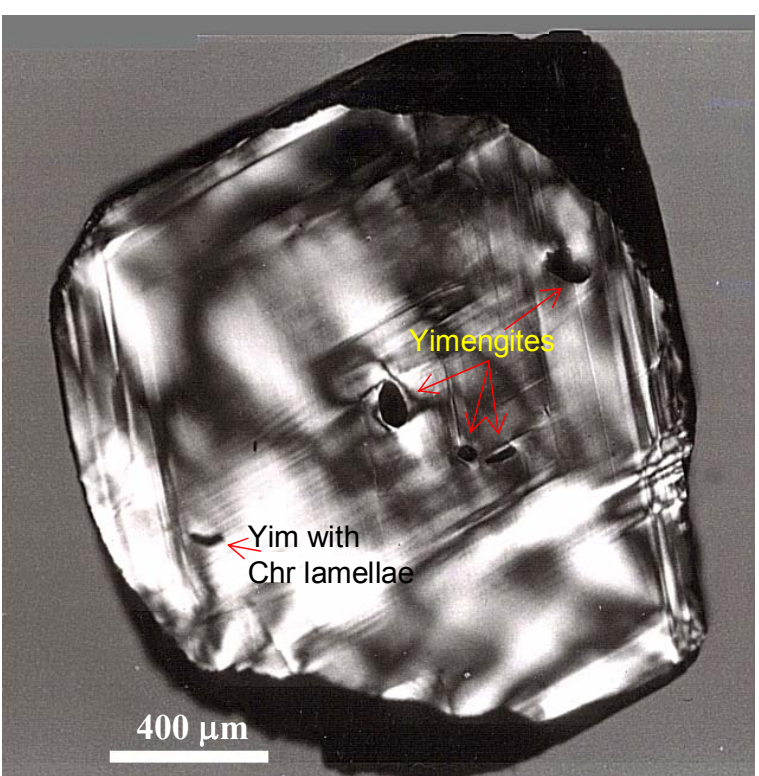

Figure 1: ABR image of a central plate of the Sese diamond showing zonally-distributed yimengite inclusions.

diamond and show the location of inclusions within different growth zones (Fig.1).

$\mathrm{N}$ content and aggregation in different diamond growth zones was determined by FTIR spectroscopy, using the Mendelssohn and Milledge (1995) technique.

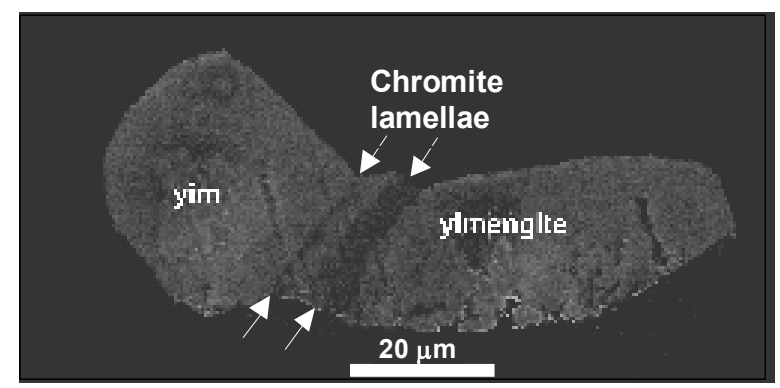

Figure 2: SEM image of the yimengite inclusion intergrown with chromite in Sese diamond.

The exposed inclusions were analysed by electron microprobe for major elements at Univerity of Western Australia. Trace elements in one of the yimengites were determined by secondary ion mass spectrometry (SIMS) on a Cameca IMS 4f ion microprobe at the University of Edinburgh, using a $10 \mathrm{kV}$ primary beam of 16 O-ions.

Dating of yimengites was made by the ${ }^{40} \mathrm{Ar} /{ }^{39} \mathrm{Ar}$ method using techniques described in Burgess et al. (1992).

\section{RESULTS}

\section{NITROGEN CONTENT AND AGgREGATION OF THE DIAMOND}

$\mathrm{N}$ content (at. ppm) in the diamond is moderate to low, decreasing from 576-311 in the core to 304-266 in the intermediate area and falling up to 220-149 in the rim. $\mathrm{N}$ aggregation $(\% 1 \mathrm{aB})$ is moderate, reducing very slightly from the core $(\sim 40)$ to the rim zones $(30 \%)$. $\mathrm{T}(\mathrm{Zn})$ and ol-sp thermometry from Sese diamond inclusion chromites suggested a range in temperature from $1050^{\circ}$ to $1225^{\circ}$, with associated Ti increase in the chromites. Applying these temperatures to Time- $\mathrm{T}^{\circ} \mathrm{C}$ constraints from $\mathrm{N}$ aggregation systematics gives a range of age possibilities from $530 \mathrm{Ma}$ kimberlite emplacement time to Archean.

\section{MAJOR ELEMENT CHEMISTRY}

SEM imaging of a yimengite inclusion revealed two oriented lamellae of chromium spinel (Fig. 2). The chemistry of this spinel (Table 1) is similar to the composition of some chrome spinel inclusions in other Sese diamonds.

Compositions of Sese yimengite and chromite lamellae are shown in Table 1. Yimengite-hawthorneite minerals have less $\mathrm{Ti}$ but $\mathrm{Cr}$-enriched compositions compared with LIMA mantle titanates (Fig. 3). Yimengite inclusions from the Sese diamond have higher $\mathrm{Al}, \mathrm{Mg}$ and $\mathrm{Sr}$ concentrations compared with the chemistry of yimengite from kimberlites.

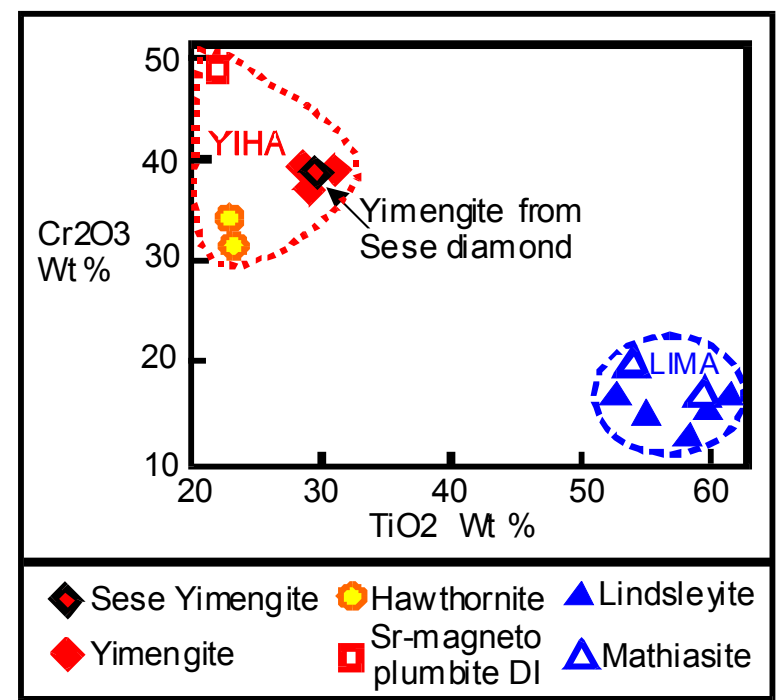

Figure 3: $\mathrm{Cr} 2 \mathrm{O} 3$ and $\mathrm{TiO} 2$ variations for alkali mantle titanates of the LIMA - YIHA series 
The calculated crystallo-chemical formula of the yimengite from the Sese diamond is:

$\left(\mathrm{K}_{0.723} \mathrm{Ba}_{0.109} \mathrm{Sr}_{0.038} \mathrm{Ca}_{0.015}\right)_{0.885}\left(\mathrm{Cr}_{4.5} \mathrm{Ti}_{3.291} \mathrm{Al}_{1.264}\right.$ $\left.\mathrm{Si}_{0.156} \mathrm{Mg}_{1.849} \mathrm{Fe}^{2+}{ }_{0.991} \mathrm{Fe}^{3+}{ }_{0.063}\right)_{12.114} \mathrm{O}_{19}$.

Table 1: Major element chemistry of syngenetic inclusion of yimengite with chromite lamella in Sese diamond

$\begin{array}{lrrr}\begin{array}{l}\text { Sample } \\ \text { Mineral }\end{array} & \begin{array}{c}1-107.9 \\ \text { Yim. incl } \\ \text { in D; av. } \\ \text { of } 5 \text { anal. }\end{array} & \begin{array}{c}1-107.9 \\ \text { Chr } \\ \text { lamella in } \\ \text { Yim DI }\end{array} & \begin{array}{c}1-107.9 \\ \text { Bulk } \\ \text { anal.(90\% } \\ \text { Yim+10\% } \\ \text { Chr) }\end{array} \\ \mathrm{SiO}_{2} & 1.06 & 0.21 & 0.98 \\ \mathrm{TiO}_{2} & 29.72 & 3.12 & 27.11 \\ \mathrm{Al}_{2} \mathrm{O}_{3} & 7.28 & 11.43 & 7.71 \\ \mathrm{Cr}_{2} \mathrm{O}_{3} & 38.66 & 55.52 & 40.43 \\ \mathrm{FeO} & 8.55 & 12.25 & 8.94 \\ \mathrm{MnO} & 0.00 & 0.21 & 0.02 \\ \mathrm{MgO} & 8.42 & 15.42 & 9.14 \\ \mathrm{CaO} & 0.10 & & 0.09 \\ \mathrm{~K}{ }_{2} \mathrm{O} & 3.85 & & 3.47 \\ \mathrm{BaO} & 1.90 & & 1.71 \\ \mathrm{SrO} & 0.44 & & 0.40 \\ \text { Total } & 99.99 & 98.16 & 100.00\end{array}$

Table 2: SIMS analysis of yimengite inclusion from Sese diamond.

$\begin{array}{lrrlrr} & \text { ppm } & \text { stdev } & & \text { ppm } & \text { stdev } \\ \mathrm{Li} & 0.37 & 0.2 & \mathrm{P} & 2.1 & 1.4 \\ \mathrm{Be} & 0.15 & 0.02 & \mathrm{Hf} & 26 & 2 \\ \mathrm{~B} & 1029 & 860 & \mathrm{Zr} & 787 & 12 \\ \mathrm{~F} & 185 & 14 & \mathrm{Sm} & 4.3 & 2 \\ \mathrm{Cs} & 3.7 & 3 & \mathrm{Gd} & 9.6 & 1.7 \\ \mathrm{Rb} & 124 & 4 & \mathrm{Dy} & 2.3 & 0.7 \\ \mathrm{Ba} & 22101 & 240 & \mathrm{Ho} & 1.6 & 0.3 \\ \mathrm{Th} & 7 & 0.2 & \mathrm{Er} & 0.35 & 0.29 \\ \mathrm{U} & 4 & 5.4 & \mathrm{Y} & 0.52 & 0.37 \\ \mathrm{~K} & 33606 & 1168 & \mathrm{Tm} & 0.27 & 0.04 \\ \mathrm{Nb} & 1587 & 24 & \mathrm{Yb} & 1.4 & 3.6 \\ \mathrm{Ta} & 81 & 8 & \mathrm{Lu} & 0.37 & 0.28 \\ \mathrm{La} & 571 & 7 & \mathrm{Ga} & 119 & 5 \\ \mathrm{Ce} & 537 & 13 & \mathrm{Ge} & 329 & 15 \\ \mathrm{Sr} & 2543 & 89 & \mathrm{Sc} & 34 & 2 \\ \mathrm{Nd} & 67 & 5 & \mathrm{~V} & 1830 & 63 \\ \mathrm{Pr} & 32 & 2 & \mathrm{Co} & 233 & 29\end{array}$

\section{TRACE ELEMENT CHEMISTRY}

The yimengite is enriched in alkaline metals: $\mathrm{K}, \mathrm{Ba}, \mathrm{Sr}$ and $\mathrm{Rb}$ and contains high amount of $\mathrm{Nb}, \mathrm{Sc}, \mathrm{V}, \mathrm{Co}, \mathrm{Zr}$ and REE elements (Tables 2).

The chondrite normalised REE pattern for the yimengite inclusion has a distinctive shape, showing enrichment in LREE and depletion in HREE similar to published data for other mantle titanates (Fig. 4).

A clear difference is the lower concentration of REE in the Sese yimengite inclusion compared to LIMA (Jones and Ekambaram, 1985). In fact the REE curve of the yimengite diamond inclusion is located inside the REE field of kimberlites and lamproites (Fig. 4).

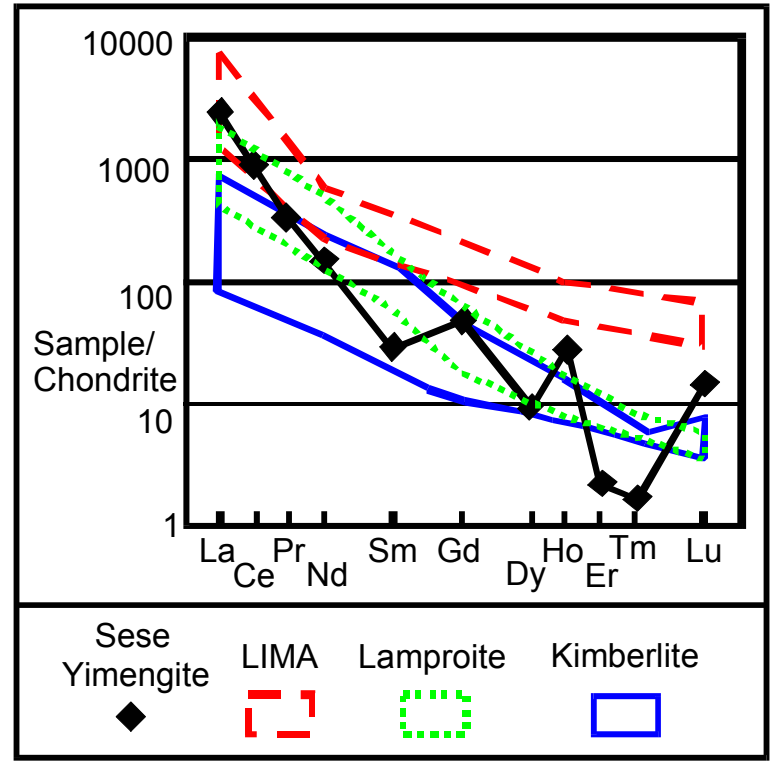

Figure 4: REE concentrations in yimengite from Sese diamond compared with other mantle titanates (lindsleyitemathiasite series) (Jones, Ekambaram, 1985), kimberlites and lamproites (Jaques et al., 1984).

\section{DATING OF YIMENGITE}

The high $\mathrm{K}$ level in yimengite make it amenable to ${ }^{40} \mathrm{Ar} /{ }^{39} \mathrm{Ar}$ dating. The largest part of the diamond plate containing 1 exposed and 3 unexposed yimengites was irradiated. The unexposed inclusions were breached using a UV laser and the inclusion fused using an IR laser. Total ages are calculated that integrate gas residing at the diamond-inclusion interface plus yimengite-held gas. Total gas ages range from close to the $530 \mathrm{Ma}$ age of kimberlite eruption to significantly older (up to $891+/-21 \mathrm{Ma}$ ). The range in total ages may reflect inclusions that are older than the kimberlite eruption age and which could have experienced 
variable gas loss possibly during polishing of the diamond plate.

\section{DISCUSSION}

The origin of previously found yimengites has been attributed to the metasomatic alteration of upper mantle chrome spinel (Nixon and Condliffe, 1989). Our identification of two oriented lamellae of chromite in the yimengite inclusion (Fig. 2) appears attributable to exsolution rather than to a metasomatic replacement.

The primary bulk analysis of the whole inclusion was calculated on the estimated proportion: $10 \%$ chromite and 90\% yimengite (Table 1). The resultant composition still matches yimengite, with a larger cation deficiency on the A-site and excess on the B-site: $\left(\mathrm{K}_{0.647} \mathrm{Ba}_{0.098} \mathrm{Sr}_{0.034} \mathrm{Ca}_{0.014}\right)_{0.793}\left(\mathrm{Cr}_{4.67} \mathrm{Ti}_{2.98} \mathrm{Al}_{1.328}\right.$ $\left.\mathrm{Si}_{0.143} \mathrm{Mg}_{1.991} \mathrm{Fe}^{2+}{ }_{0.69} \mathrm{Fe}^{3+}{ }_{0.403}\right)_{12.20} \mathrm{O}_{19}$.

The low Cr- and Ti-containing spinel lamellae (Table 1) resemble in chemistry some chromite inclusions in other Sese diamonds. Similar spinel was found in association with yimengite from Venezuela, considered as the first step in spinel-yimengite metasomatic replacement (Nixon and Condliffe, 1989).

Two main types of chromite inclusion chemistry were recognised in Sese diamonds (Fig. 5):

Group 1, predominant and common for chromites in diamonds elsewhere, is very high in $\mathrm{Cr}_{2} \mathrm{O}_{3}$ (>63 wt.\%), medium in $\mathrm{Al}_{2} \mathrm{O}_{3}$ (6-7 wt.\%), high in $\mathrm{MgO}$ (13-14 wt.\%) and low in $\mathrm{TiO}_{2}(0-0.4$ wt.\%).

Group 2 is characterised by moderate $\mathrm{Cr}_{2} \mathrm{O}_{3}$ (62-56 wt.\%), high $\mathrm{Al}_{2} \mathrm{O}_{3}$ (6-14 wt.\%), and very rich $\mathrm{MgO}$ (1416 wt.\%) and by a significant amount of $\mathrm{TiO}_{2}(1.3-2.3$ wt.\%). The chromite intergrown with yimengite has Group-2 chemistry. Such a composition for diamond inclusions is very rare, but was reported for chromites from River Ranch diamonds (Kopylova et al., 1997).

A temperature of $1050^{\circ}$ for Group 1 and $1225^{\circ}$ for Group 2 diamond inclusion chromites was determined by ol-sp and $\mathrm{T}(\mathrm{Zn})$ thermometry.

The general evolutionary change of Sese diamond inclusion chromites is from $(\mathrm{Fe}, \mathrm{Cr})$ to $(\mathrm{Mg}, \mathrm{Al}$ and $\mathrm{Ti})$. Such enrichment in $\mathrm{Mg}$ and $\mathrm{Al}$ can take place during diamond growth through metasomatism (Fig. 5). This change of chemistry may be indicative of a link to the later formation of yimengite by metasomatic

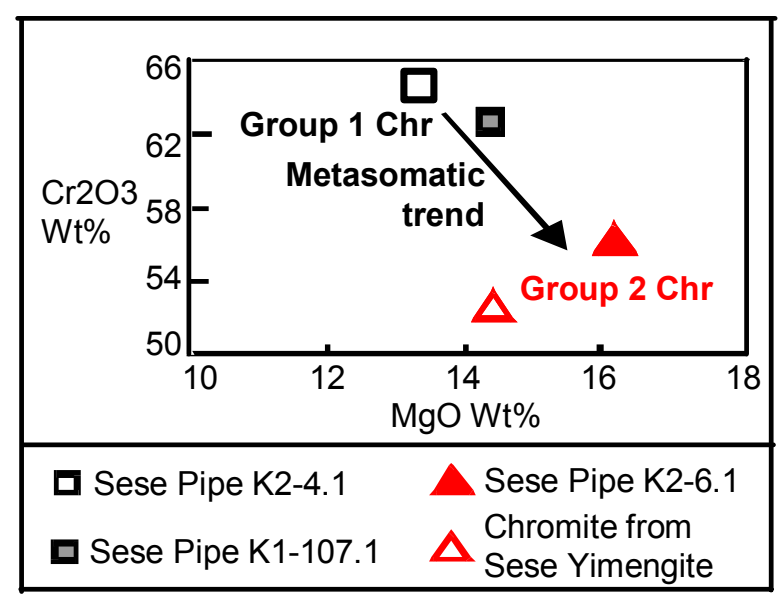

Figure 5: Trend of chemistry of chromite inclusions from Sese diamonds.

replacement of spinel by fluid enriched in $\mathrm{Ti}, \mathrm{K}, \mathrm{Ba}, \mathrm{Sr}$ and LREE.

Whereas ${ }^{40} \mathrm{Ar} /{ }^{39} \mathrm{Ar}$ dating of yimengites gave ages ranging from $530 \mathrm{Ma}$ to $891 \mathrm{Ma}, \mathrm{T}(\mathrm{Zn})$ and ol-sp thermometry from Sese diamond inclusion chromites combined with $\mathrm{N}$ aggregation systematics suggests age possibilities from $530 \mathrm{Ma}$ kimberlite emplacement time to Archean and does not help resolve the age of the yimengite-bearing diamond.

The Sese occurrence may be part of a wider regional event - Kopylova et al. (1997) has described diamond inclusions from River Ranch kimberlite consisting of other REE titanates enriched in $\mathrm{Ti}$ (Cr-chevkinite, Sr-KCr-loparite) plus chromites similar to our Group-1 and Group-2 spinel chemistry.

The identification of yimengite as syngenetic inclusions in diamond provides evidence about the close association and genesis of these minerals. Although very rare, yimengite and the other LILE minerals could be considered as indicator minerals for diamonds.

\section{CONCLUSIONS}

Zonally distributed syngenetic inclusions of yimengite identified in peridotitic diamond from Sese kimberlite demonstrate their genetic association. This textural evidence indicates diamond and yimengite coexistence during metasomatism of upper mantle chromite-bearing harzburgites at depths of 120-150 km.

Sese yimengite inclusions have higher contents of $\mathrm{Al}$, $\mathrm{Mg}$ and $\mathrm{Sr}$ and low concentrations of $\mathrm{Fe}^{3+}$ compared to 
previously published compositions for this mineral. The level of REE-elements in Sese yimengite is similar to those in kimberlite and lamproite rocks.

Whilst ages from $530 \mathrm{Ma}$ (kimberlite eruption age) to $891 \mathrm{Ma}$ were determined from ${ }^{40} \mathrm{Ar} /{ }^{39} \mathrm{Ar}$ dating of yimengites, time- $\mathrm{T}^{\mathrm{O}} \mathrm{C}$ constraints from $\mathrm{N}$ aggregation systematics combined with $\mathrm{T}(\mathrm{Zn})$ and ol-sp thermometry gave a range of possible ages from 530 Ma to Archean.

The general trend of chemistry for Sese chromite diamond inclusions: $\mathrm{Fe}, \mathrm{Cr} \rightarrow \mathrm{Mg}, \mathrm{Al}$, Ti signifies metasomatic events during diamond formation, with increasing of temperature by $175^{\circ} \mathrm{C}$. Such change of chemistry might indicate that yimengite forms from a fluid enriched in $\mathrm{Ti}, \mathrm{K}, \mathrm{Ba}, \mathrm{Sr}$ and REE by metasomatic replacement of the chrome-spinel. It is important that diamond growth continued during this upper mantle metasomatism, in spite of a general believe that diamonds are resorbed in such environments.

\section{AKNOWLEDGMENTS}

Rio Tinto Zimbabwe Ltd and Rio Tinto Mining and Exploration Ltd are thanked for kind permission to publish the paper. R. Trautmann is thanked for taking RTIR measurements of the diamond and $\mathrm{S}$. Kearns for producing the SEM image of the yimengite inclusion.

\section{REFERENCES}

Burgess, S.R., Turner, G., Harris, J.W., 1992. 40Ar/39Ar laser probe studies of clinopyroxene inclusions in eclogitic diamonds. Geochim. Cosmochim. Acta 56, 389-402.

Dong, Z., Zhou, J., Lu Q., Peng, Z., 1983. Yimengite, $\mathrm{K}(\mathrm{Cr}, \mathrm{Ti}, \mathrm{Fe}, \mathrm{Mg})_{12} \mathrm{O}_{19}$, a new mineral from China. Kexue Tongbao Bulletin Science 15, 932-936 (in Chinese).

Haggerty, S.E., 1987. Metasomatic mineral titanates in upper mantle xenoliths. In Nixon, P.H., (Ed.), Mantle xenoliths. J.Wiley and Sons Ltd., Chichester, pp. 671690.

Jaques, A.L., Lewis, J.D., Smith, C.B., Gregory, G.P., Ferguson, J., Chappell, B.W., McCulloch, M.T., 1984. The diamond-bearing ultrapotassic (lamproitic) rocks of the West Kimberley region, Western Australia. In Kornprobst, J., (Ed), Kimberlites I: Kimberlites \& Related Rocks, Proc. 3rd Int. Kimb. Conf., Developments in Petrology IIA, Elsevier, pp. 225-254.
Jones, A.P., Ekambaram, V., 1985. New INAA analysis of mantle derived titanate mineral of crichtonite series, with particular reference to the rare earth elements. Amer. Mineral. 70, 414-418.

Kiviets, G.B., Phillips, D., Shee, S.R., Vercoe, S.C., Barton, E.S., Smith, C.B., Fourie, L.F., 1998. ${ }^{40} \mathrm{Ar} /{ }^{39} \mathrm{Ar}$ dating of yimengite from Turkey Well kimberlite, Australia: The oldest and the rarest. Ext. Abstr. $7^{\text {th }}$ International Kimberlite Conference, pp.432-434.

Kopylova, M.G., Rickard, R.S., Kleyenstueber, A., Taylor, W.R., Gurney, J.J, Daniels, L.R., 1997. First occurrence of strontian $\mathrm{K}-\mathrm{Cr}$ loparite and $\mathrm{Cr}$ chevkinite in diamonds. Proc. Sixth Intern. Kimberlite Conference, vol. 2: Diamonds: Characterization, Genesis and exploration, Russian Geology and Geophysics 38, 405-420.

Mendelssohn, M.J., Milledge H.J., 1995. Geologically significant information from routine analysis of the mid-infrared spectra of diamonds. Intern. Geol. Rev., 37 (2), 95-110.

Nixon, P.H., Condiffe, E., 1989. Yimengite of K-Ti metasomatic origin in kimberlitic rocks from Venezuela. Min. Mag. 53, 305-309.

Peng, Z., Lu, Q., 1985. The crystal structure of yimengite, Sci. Sinica (Series B) 28, 882-887.

Sobolev, N.V., Yefimova, E.S., Kaminsky, F.V., Lavrentiev Y.G., Usova L.V., 1988. Titanate of complex composition and phlogopite in the diamond stability field. In Sobolev, N.V., (Ed.), Composition and processes of deep seated zones of continental lithosphere. Nauka, Novosibirsk, pp. 185-186.

Contact: GP Bulanova, 10 Upper Camden Place, Bath BA15HX, United Kingdom, E-mail:

galina_bulanova@hotmail.com 